\title{
INFLUENCE OF MARKETING COMMUNICATIVE STRATEGIES ON CONSUMER BEHAVIOUR: A CASE OF THE HIGH-TECHNOLOGY MARKET OF UKRAINE
}

\author{
Victoria ZHURYLO', Olga PRYGARA² \\ Taras Shevchenko National University of Kyiv, Ukraine
}

\begin{abstract}
The purpose of the study is to research consumer behaviour types and to develop marketing strategies of communicative influence on the consumer in the high-technology goods market. Methodology. Marketing research in Ukrainian market of high-tech goods is conducted to define motivations of the consumers and the peculiarities of their market behaviour. The profiles of target customers are developed and the typology of consumer behaviour is formed, based on the reasons of purchasing of high-tech goods and on the level of consumer involvement in the purchasing process. Results showed that Highly Rational, Cautious, and Demonstrative behaviours can be observed in case of high consumer involvement in the buying process. Rationally-Confident, Comfortable, Adaptive behaviour can be observed in the case of low involvement. The peculiarities of communicative influence for each type of consumer behaviour in the market of high-tech goods are determined and the appropriate strategies of marketing communication are offered. Practical implementation. Strategies of communicative influence and communication sources depend on consumer behavioural types and the stage of the process of adopting innovations. In case of highly rational consumer behaviour, generic strategy, benefit strategy, and unique technical advantage strategies are recommended to be used as the main communicative strategies. Benefit strategy, unique technical advantage strategy, positioning strategy should be used in the case of rationally confident behaviour. The technology of intrusion, intimidation, positioning strategy, affective strategy, and resonance strategy should be used in the case of cautious consumer behaviour. Brand strategy should be used in the case of demonstrative consumer behaviour. The communicative strategies of product positioning and the strategy of resonance can be used in the case of comfortable consumer behaviour. Brand strategy is the main communicative strategy in the case of adaptive consumer behaviour. Communicative influence and communication sources depend on the stage of adopting innovations: 1) awareness, 2) attitude formation, 3) decision, 4) confirmation, 5) implementation. The main communicative channels on the first and second stage of the process of adopting innovations are: exhibition activity, TV advertising, outdoor and print advertising, Internet advertising, specialized publications, testing centres for goods, state educational programs. The main communication channels on following stages are testing centres, the advice of friends and acquaintances, customer's experience, the advice of vendors-consultants.
\end{abstract}

Key words: high-tech goods, consumer motives, type of consumer behaviour, communicative influence, strategies of marketing communication.

JEL Classification: F23, L10, L20, M21, M37

\section{Introduction}

The company sending the communication message aims to inform, persuade, and force consumers to act in a way that is in line with its market interests. It predetermines the desired response from the consumer and sends a message. At the same time, the effectiveness of developing a communication strategy depends on the ability of the communicator to listen to the signals of the market, to take into account the influence of socio- cultural factors and the environment of the consumer on the formation of his own preferences. Therefore, the research of the main motivations of consumers of hightech goods, identification of the features of their market behaviour, which forms the basis for developing an effective strategy of communicative influence, becomes of special significance. The difficulty of forecasting of the high-tech markets development dynamics, incertitude of competitive environment, rapid changes in technologies

\footnotetext{
Corresponding author:

${ }^{1}$ Department of International Economics and Marketing, Taras Shevchenko National University of Kyiv. E-mail: vikzhur@gmail.com

${ }^{2}$ Department of International Economics and Marketing, Taras Shevchenko National University of Kyiv.

E-mail: olgaprygara@gmail.com
} 
and products, high level of market and technological uncertainty of consumers and manufacturers cause the need to look for the mechanisms of influence on the mentioned markets development, the development of modern market tools of consumers' demand formation, including the formation of effective communicative strategies of high-tech enterprises.

\section{Review of theory and literature}

During the last decades, a great number of scientific and practical works were published, dedicated to the research on consumer behaviour and tools of marketing influence on the consumers' decision. The publications of such authors as R. Blackwell, P. Miniard, J. Engel (2006), M. Solomon (2012), Statt (2003), G. Foxall, R. Goldsmith, S. Brown (2001), W. Wells (2014), I. Ajzen, M. Fishbein (1991, 2000), T. Hansen (2005) are particularly noteworthy. In their works, researchers describe mechanisms of consumer decisions and define the factors, which influence their preferences and behaviour in the market on the whole, study the system of the researching methods of existing problems and forecasting the future ones. Big amount of literature sources is devoted to the problem of the companies' communicative strategies creation: these topics cover D. Aaker (2001, 2007, 2009), S. Moriarty, T. Duncan (1998, 2002), L. Percy. (1997), P. Smith, C. Berry (1998), P. De Pelsmacker, M. Geuens, J. Van den Bergh (2004), D. Ogilvy (1983), K. Rotzoll (1986, 1991) and others. However, the marketing tools, strategies, and mechanisms discussed in these studies cannot be used by high-technology producers without appropriate adjustments and modifications taking into account specific features of the product and particularities of consumer behaviour.

Many scientific works are dedicated to the functioning of high-tech products markets and to the research of market activity features of business entities in these markets. Among them, it is necessary to distinguish R. Rexroad (1983), J. Mohr, S. Slater (2010), W. Shanklin, J. Ryans (1984), R. Moriarty, T. Kosnik (1989), G. Moore (2014), M. Raynor, H. Riggs (1983). Considering special aspects of marketing activity and marketing instruments application on these markets, scientists take up the position that specific features of the commodity, market, and market interests of its agents impact the formation of marketing strategies. However, many scientists concentrate their attention primarily on the specific aspects of the functional strategies development. Scientists emphasize that high tech industries contribute to features some modification of the classic marketing strategies and offer a variety of strategies based on specific attributes (e.g.: for periodto-market technologies for the life cycle, the period of adaptation latest products, etc.).
Thus, the communicative influence mechanisms on the consumer decisions in the high-tech goods market are not described fully enough, this issue stays partially researched for today. In our opinion, it is a matter to determine the actual cause-and-effect relationships between the motivational features of the target consumer's behaviour and the type of communication strategy of a high technology company with the aim of the most effective impact on the market.

The aim of this article is to identify the specific of the communicative influence on target consumer segments in the high-tech goods market based on the research of the consumer behaviour types. In fact, it is the explanation of the communicative influence type choice - rational, irrational or mixed, which prepares the ground for the strategies creation and companies' marketing communication technologies. The key features of the consumer motivation and behavioural process are the basis of target consumer behaviour classification in the researched market and of creating the target segments profiles. To reach the purpose of this research, the following tasks are set and accomplished: 1) to identify the peculiarities of consumer motivation and consumer behaviour in Ukrainian high-tech goods market; 2) to create the target consumers profiles; 3 ) to develop a classification of consumers behaviour based on motivational peculiarities of their market behaviour; 4) to explain the specific features of communicative influence of every type of consumer behaviour.

\section{Data Collection}

Results of the research on consumer motivation and peculiarities of their market behaviour are the informational basis of the strategies of marketing communications on the target segments. To study the consumer market behaviour in the high-tech goods market, we have conducted the marketing research, during which qualitative and quantitative methods of collecting primary marketing information were used. The quantitative method included focus-group survey of target consumers, who have had the experience in purchasing and using high-tech goods. There were 3 focus-groups, in which 26 respondents participated. The quantitative method included collecting necessary information with the help of mass sample observation (sample group included 246 respondents). The necessity to use respondent focus-group survey was due to the complexity of forecasting what consumers of high-tech products would do and high probability of wrong marketing theory creation, whose usage would blunt the effectiveness and reach the research objective significantly. That is why the coherent use of these survey methods allowed getting accurate market information. The process of focus-group and sample survey conducting was based on the standard selection procedure and the target respondents' survey. 


\section{Empirical assessment of consumer behaviour formation in the market of high technology goods and the peculiarities of the communicative influence on target consumers}

The key factor, which determines the consumer behaviour in the high-tech goods market in Ukraine, is the type of purchasing decision or the main motivation to the purchasing. It is widely accepted that there is no unified and overall applicable motives classification. The compilation of human motives classification depends primarily on the aims and objectives of a study and its practical application. In marketing, consumer motivations are traditionally classified into rational and emotional, the similarity between which lies in the fact that they are both simultaneously involved in the consumer choice in the market. While making a decision to purchase something, the consumer is not guided by rational or emotional motives only, although the significance of both can vary crucially for different segments. Rational motives are considered in traditional economic aspect assuming that the consumer observes all possible alternatives and makes his choice to maximize the profit and get the certain practical benefit using this product. Emotional motivation is related to the consumers wish to reach the certain emotional state and determined by subjective self-perception, his emotional expectations from the purchase. Usually, when the consumer makes a decision to buy something, his emotional field may contain rational and emotional motives simultaneously. Although some of them have the edge on another and differ depending on target segment's profile. According to research results, we created a classification of the main motives of the destination high-tech goods consumers and determined the main motives hierarchy in two age segments (segment 1 - age 17-29, segment 2 - age 30-45), which is proper to studied market (Fig. 1). It should be noted that the group of social motives was singled out, it shows the consumers desire for the socialization, their achievements' demonstration, using the social status elements, and it is conditioned by formed products' social position on certain market segments as highstatus one.

Considering the researches of Ukrainian consumers' motivations, we defined three basic rational motives to purchase high-tech products: 1) profitability motive: the desire of the consumer to rationally and economically spend time, effectively managing costs; 2) convenience and additional benefits motive: the consumer's desire to facilitate and simplify their actions, to spend less effort to solve problems, to improve the quality of life and provide a high level of comfort; 3 ) security motive: the need for self-secure, for being confident in the future, for not being preoccupied with their health and property. Ensuring the sustainability, stability, confidence in future self-fulfilment will be demanded by the society. In their turn, emotional motives are the following: 1) satisfaction motive: the desire of a consumer to get psychological satisfaction from the possession and use of the goods, to meet the aesthetic needs; 2) freedom motive: the human need for autonomy and independence in various spheres; the desire to be mobile, energetic, take a proactive stance (that also characterizes independence of a consumer); 3 ) motive of individuality: the consumer wish to be unlike others, to state their uniqueness and exclusiveness with the help of new technologies usage. 4) self-fulfilment motive: the need for personal growth and development, success, self-esteem, and self-affirmation; this motive expresses the willingness of an individual to realize their full potential; 5) recognition motive: the desire of a consumer to form their status in the society, to improve the

\begin{tabular}{|c|l|c|c|c|c|}
\hline $\begin{array}{c}\text { Motives } \\
\text { hierarchy }\end{array}$ & \multicolumn{1}{|c|}{$\begin{array}{c}\text { Consumer motives } \\
\text { segment 1 }\end{array}$} & \multicolumn{1}{|c|}{ Consumer proportion (confidence limit), \% } & $\begin{array}{c}\text { Consumer motives } \\
\text { segment 2 }\end{array}$ & $\begin{array}{c}\text { Motives } \\
\text { hierarchy }\end{array}$ \\
\cline { 2 - 5 } $\mathbf{1}$ & \multicolumn{1}{|c|}{ recognition motive } & $34-52$ & $38-58$ & self-fulfilment motive & $\mathbf{1}$ \\
\hline $\mathbf{2}$ & $\begin{array}{l}\text { Fig. 2. Motivational segmentation of } \\
\text { Ukrainian high-tech goods consumers } \\
\text { Source: compiled by the authors } \\
\text { according to the research results self- } \\
\text { fulfilment motive }\end{array}$ & $32-48$ & $34-54$ & $\begin{array}{c}\text { sonvenience and } \\
\text { additional benefits } \\
\text { motive }\end{array}$ & $\mathbf{2}$ \\
\hline $\mathbf{3}$ & $\begin{array}{l}\text { convenience and additional benefits } \\
\text { motive }\end{array}$ & $24-42$ & $19-37$ & profitability motive & $\mathbf{3}$ \\
\hline $\mathbf{4}$ & profitability motive & $18-36$ & $9-23$ & satisfaction motive & $\mathbf{4}$ \\
\hline $\mathbf{5}$ & social affiliation motive & $8-22$ & $7-21$ & knowledge motive & $\mathbf{5}$ \\
\hline $\mathbf{6}$ & motive of individuality & $7-20$ & $4-16$ & freedom motive & $\mathbf{6}$ \\
\hline $\mathbf{7}$ & satisfaction motive & $5-17$ & $2-7$ & $\begin{array}{c}\text { social affiliation } \\
\text { motive recognition } \\
\text { motive }\end{array}$ & $\mathbf{8}$ \\
\hline $\mathbf{8}$ & knowledge motive freedom motive & $3-13$ & & $\mathbf{8}$ \\
\hline
\end{tabular}

Fig. 1. The main consumers' motives in two age segments

Source: the authors' calculations according to primary marketing information 
image, to draw attention of their surrounding; 6) social affiliation motive: the desire of a consumer to keep up with their surroundings, to follow current trends, to meet the requirements of their time, to be competent in modern achievements and different areas. The last three motives are classified as socio-emotional and reflect the consumer's desire for the socialization, demonstration of their achievements, using elements of social prestige. These motives are caused by the already developed social position of a product that is considered to be product status.

As it can be seen from the data given above, the Ukrainian youth needs are socially-oriented and, on the contrary, middle-aged consumers' needs are connected with self-realization and they belong to rationallyemotional motivation. According to the results, the motivational segmentation of Ukrainian consumers in the high-tech market is made and the profiles of four target groups are defined (Fig. 2).

One of the main factors, which influence the formation of certain types of consumer behavioural models in a studied market, is the factor of target consumer involvement to the process of purchasing, which shows the level of interest and understanding of the importance of meeting the urgent demand and solving the existing problem. It is determined that such factors define the level of consumer involvement: the level of perceived risk in the process of gathering information and market risks evaluating, emotional commitment to the certain high-tech brand and individual consumers' characteristics (for example, "technophiles" segment shows the high level of involvement in majority of purchasing situations). Let us analyse the consumer risk perception in details. According to received data, the financial risk connected with high price gains a significant importance (it was mentioned by $68.5 \%$ of surveyed). The consumers also mention such kinds of risks which influence their purchase decisions:

- time risk $-35.0 \%$ of surveyed will put the purchase back waiting for the more modern model;

- exploitation risk $-30.0 \%$ of surveyed beware of the problems connected with the technical exploitation of goods;

- service risk - $22.0 \%$ of surveyed are a bit afraid of problems with maintenance service;

- informational risk $-21.0 \%$ of surveyed can refuse the purchase due to negative information about the product or manufacturer;

- $23.0 \%$ of surveyed will put the purchase back due to lack of needed information.

Consequently, we have created the typology of purchasing behaviour among Ukrainian consumers, in which such types of purchasing behaviour depending on the reason for purchasing the high-tech goods and the level of consumer involvement in the process of purchasing can be observed: highly rational, rationallyconfident, cautious, comfortable, demonstration, and adaptive (Fig. 3). These purchasing behaviour types differ from one another by the character of making the purchasing decision, the level of involvement in the purchasing process, the choice of information processing strategy, the number of market alternatives,

\begin{tabular}{|c|c|c|c|}
\hline Technophiles & Rationalists & Idealists & High-status consumers \\
\hline $\begin{array}{l}\text { Age: youth, middle- } \\
\text { aged people } \\
\text { Gender: prevailing } \\
\text { men } \\
\text { Income level: } \\
\text { prevailing middle class }\end{array}$ & $\begin{array}{l}\text { Age: youth, middle } \\
\text { aged and elderly } \\
\text { people } \\
\text { Gender: men and } \\
\text { women } \\
\text { Income level: low, } \\
\text { middle and high }\end{array}$ & $\begin{array}{l}\text { Age: middle aged and } \\
\text { elderly people } \\
\text { Gender: prevailing } \\
\text { men } \\
\text { Income level: middle, } \\
\text { high }\end{array}$ & $\begin{array}{l}\text { Age: youth, middle-aged } \\
\text { people } \\
\text { Gender: men and women } \\
\text { Income level: middle and } \\
\text { high }\end{array}$ \\
\hline $\begin{array}{l}\text { Dominant motives } \\
\text { satisfaction motive } \\
\text { knowledge motive } \\
\text { self-fulfilment motive } \\
\text { profitability motive } \\
\text { freedom motive }\end{array}$ & $\begin{array}{l}\text { Dominant motives } \\
\text { - profitability motive } \\
\text { - convenience and } \\
\text { additional benefits } \\
\text { motive } \\
\text { - self-fulfilment } \\
\text { motive } \\
\text { - freedom motive } \\
\text { - security motive }\end{array}$ & $\begin{array}{l}\text { Dominant motives } \\
\text { 'satisfaction motive } \\
\text { 'motive of individuality } \\
\text { convenience and } \\
\text { 'dditional benefits } \\
\text { notive } \\
\text { - self-fulfilment } \\
\text { motive }\end{array}$ & $\begin{array}{l}\quad \text { Dominant motives } \\
\text { - satisfaction motive } \\
\text { - motive of individuality } \\
\text { - convenience and } \\
\text { additional benefits } \\
\text { motive } \\
\text { - recognition motive } \\
\text { - social affiliation } \\
\text { motive }\end{array}$ \\
\hline
\end{tabular}

Fig. 2. Motivational segmentation of Ukrainian high-tech goods consumers

Source: compiled by the authors according to the research results 


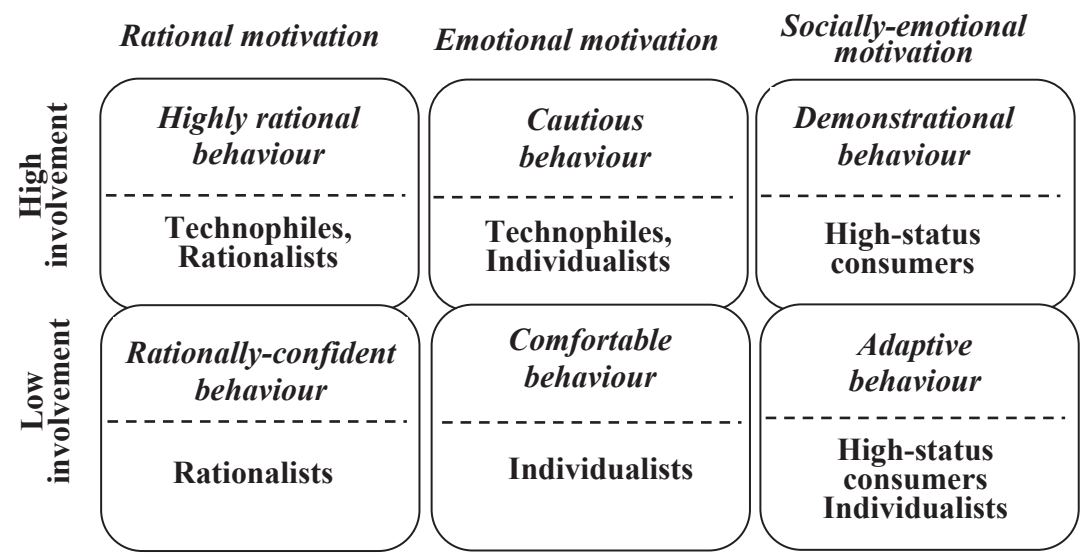

Fig. 3. Types of purchasing behaviour of Ukrainian high-tech goods consumers

Source: compiled by the authors

which are estimated, the number of external sources, involved during the looking for the information, the time of purchasing decision. Let us review the consumer behavioural reactions according to every behavioural type more detailed.

Highly rational behaviour is observed in the high-risk situations and consumer wishes to have the maximum benefits from the products' technical capabilities. High level of financial, exploitation and time risk, and also the risk of an information gap in new technology or product force the consumer to look for information thoroughly. Rationally-confident behaviour is inherent to consumers during rational purchasing with a low level of perceived risk, which reduces the consumer sensibility to the price. Usually, this behaviour type is observed during the repurchase. The consumers who have never bought the particular high-tech product before but have the experience of using the product from relative product group can also demonstrate the rationally-confident behaviour. Cautious behaviour is characterized by high complexity of variants evaluation before the purchasing. Despite the consumers' emotional involvement in the purchase, he looks for the best alternative in the market. The consumer demonstrates the highly rational approach in the process of looking for information. Demonstrative behaviour is inherent to the consumers who strive for the attention and inclined to the demonstrative consuming. The important factor is a degree of a market novelty of the product because the demonstration of outdated even though expensive model does not contribute to the consumer higher social status. Comfortable behaviour is characterized by the easy decisions about the purchase and is inherent to the consumers with high income level who want to get the emotional satisfaction from the purchasing and usage. Consumers demonstrate high external search activity paying attention to the functions, brand image, and style. The emotions experienced by the consumer during the first experience of product consuming will define the further attitude to the goods. Adaptive behaviour - this behavioural type can be characterized as "socially-induced". The consumer purchase the product desiring to keep up with surrounding people, to be "socially adaptive" while inspecting the favourable social commitment to the product, its active usage by the surrounding people and feeling low financial, exploitation, and other market risks. Having defined the types of customers purchasing behaviour, let us develop recommendations for marketing communications strategies with every type of purchase (Fig. 4).

Russian scientists in the field of communications Pyrogova Y. K. and Parshyn P. B. provide an explanation of rational and emotional strategies of communicative influence (Pyrogova Y. K. and Parshyn P. B., 2000). Thus, for highly rational consumer behaviour, rational strategies and communication technologies should be used. Rational consumer strives to achieve optimum amount of benefits. Communication should appeal to provide all technical specifications of the product, information concerning maintenance, service, and price. Communication, based on informing on benefits and unique technical advantages (UTA) of the product can minimize high level of perceived risk by customers with highly rational behaviour.

Rationally-confident consumer behaviour is observed during the repurchase. Like in the case of highly rational consumer behaviour, rational strategies and communication technologies should be used: communication, based on informing on benefits and technical advantages of the product. Besides, in this case, the consumer makes the decisions based on the previous positive purchasing experience and, as a result, attachment to the certain manufacturers' product is formed. So, positioning strategy is also important here.

Cautious consumer behaviour is characterized by high emotional involvement in the purchase. And the consumer demonstrates the highly rational approach in the process of decision-making. In a situation of 


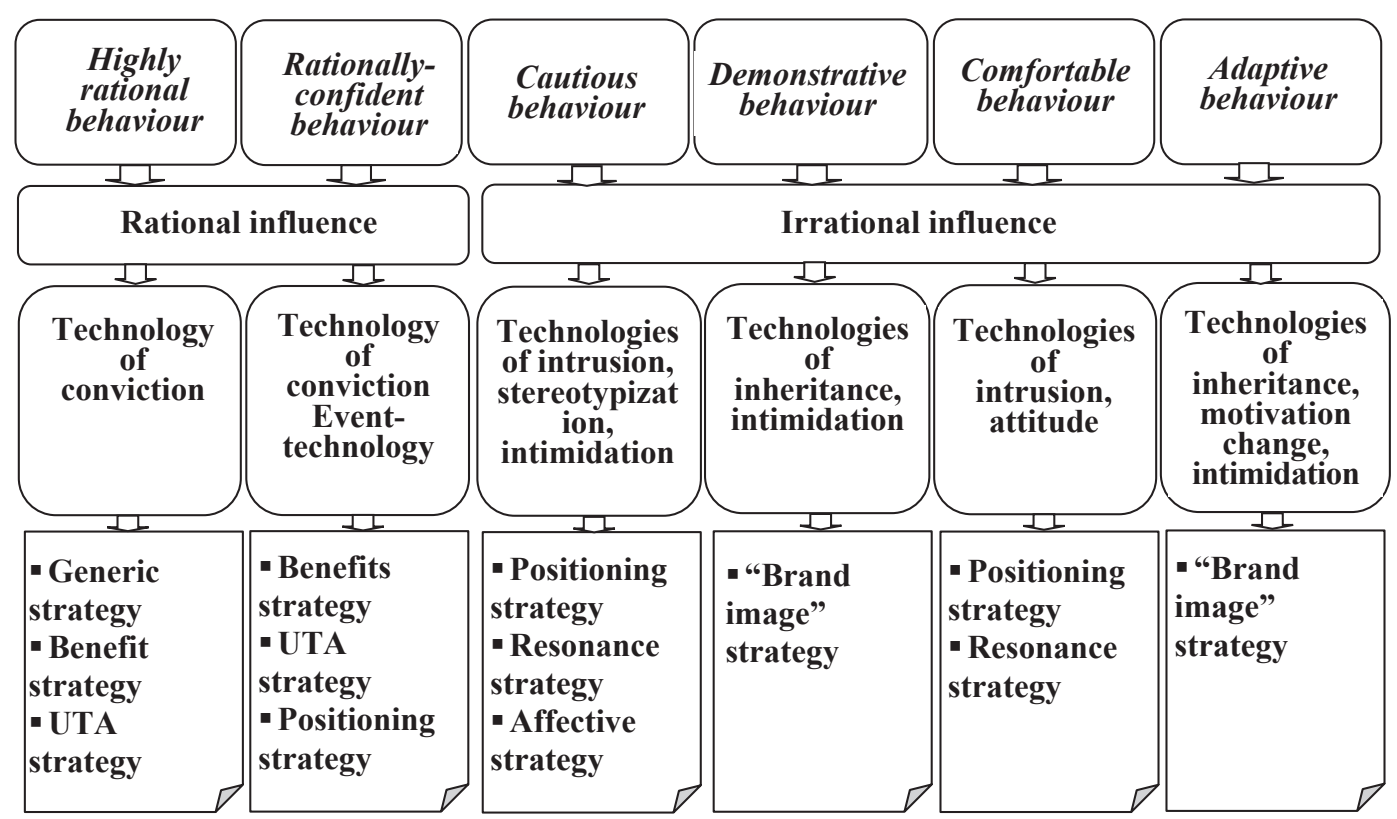

Fig. 4. Specific features of communicative influence for different consumer behavioral types on the high-tech goods market

Source: compiled by the authors

the high level of financial risk, the consumer will probably postpone the purchase for some time. Thus, the technology of intrusion, stereotypes creation, intimidation, positioning strategy, affective strategy, and resonance strategy due to irrational influence on decision-making process can be used here.

Demonstrative consumer behaviour is characterized by demonstrative consuming. Brand image, price, and market novelty of product are the most important factors of decision-making process, so brand image strategy is the main communicative strategy in this case. Comfortable consumer behaviour is highly emotional behaviour. It is based on emotions experienced by the consumer during the first experience of product usage. So, the main communicative strategies are positioning strategy and the strategy of resonance. Adaptive consumer behaviour is "socially-induced" behaviour and consumer decision is influenced mostly by reference groups. Brand strategy is the main communicative strategy in this case.

Figure 5 shows the model of communicative influence on the consumer market behaviour on high tech goods market. Strategies of communicative influence depend on consumer behavioural types. Besides, communicative

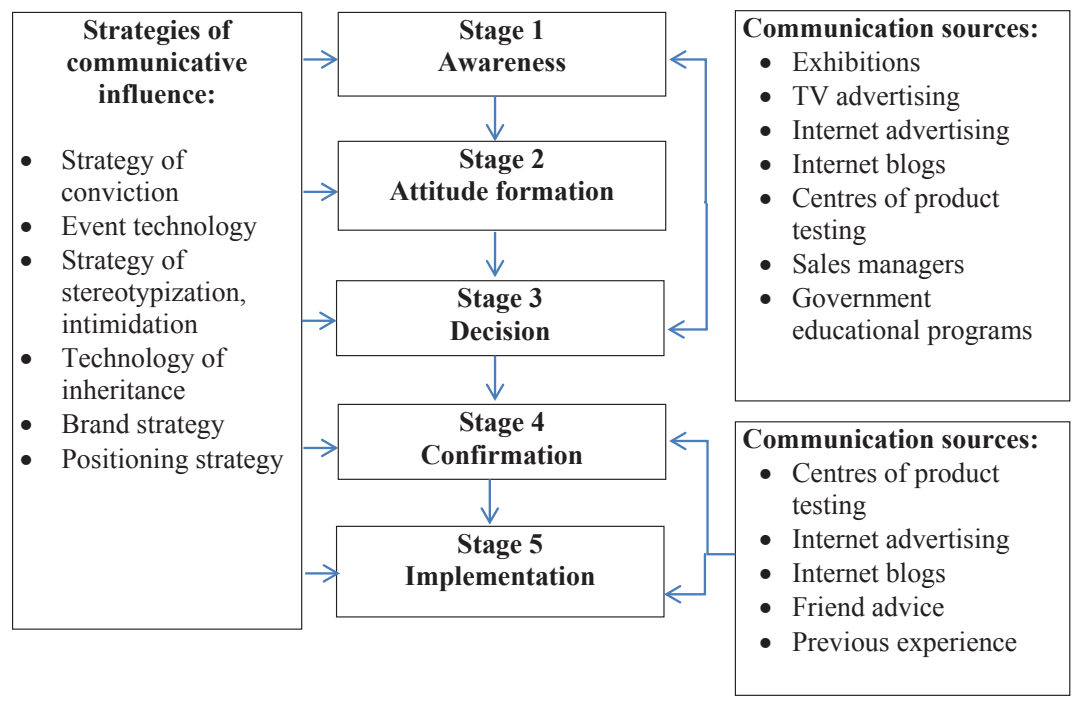

Fig. 5. Model of communicative influence on the consumer market behaviour in the high tech goods market 
influence and communication sources depend on the stage of adopting innovations. The process of adopting innovations consists of five stages: 1) awareness; 2) attitude formation; 3) solution; 4) development; 5) confirmation (E. Rogers, 1960). In our opinion, the proposed model can be used for considering the behaviour of consumers of new technological products and the formation of a technological culture of consumption.

Stages of consumer behaviour of high-tech products on Ukrainian market:

Stage 1 - Awareness. On the first stage, the potential user receives the first information about the product, either at the expense of either a quick advertisement, either through the vision of the product in action or after hearing the information from acquaintances. The direction of communicative influence is cognitive. So, rational strategies should prevail through the technologies of UTA (if there are competitors, they are few and they are technologically strong enough, and we decide to oppose them, with an emphasis on a clear advantage); benefit strategy (allows focusing on product attributes comparing to competitive ones). If we talk about unique high tech product, technology monopoly or innovative product, the generic strategy can be used.

Stage 2-Attitude formation. At this stage, a potential user will appeal to a significant amount of information sources, will interpret the information obtained to form the minds of the advantages/disadvantages of the company and the product. The direction of influence is affective; accordingly, irrational strategies come to the forefront, although rational strategies also take place. Positioning strategy (where among the criteria of positioning rational and emotional components may be used) and brand strategy are the most effective strategies of communicative influence.

The strategy of resonance is to establish a link between the advertised brand and a certain situation, a situation that has become stereotyped images - for example, the use of this high tech product that means success in a career and promotion on the career ladder. It is possible to use methods of suggestion, for example, identification.

On the first and second stages, the effective channels of communication include:

- Exhibition activity: exhibitions are devoted to new technologies and developments. Both professionals and ordinary users interested in technology innovations visit them.

- Television. The most popular channel is television. The probability that the consumer will receive the required message increases several times.

- Outdoor advertising and print advertising. The presence of external and printed advertising will strengthen the effect of advertising on television. Increase the likelihood of consumer interest in the novelty.
- Internet advertising: banners. Pop-up banners in the middle of a web page usually nerve the consumer but often the information presented on them has a high memory.

- Blogs. On blogs, consumers can also get product information, even hear first reviews.

- Specialized publications usually make an overview of the most expected new products, thus, they are interested in the consumer, encourage him to further search or passively campaign for the purchase of new items.

- Testing centres for goods. In Ukraine, they are usually located either in the store or at exhibition events. - Recommendations from friends/relatives. Families, friends, relatives could get information about the device before or already use it.

- Sales consultants. The essence of the advice of sellers-consultants in the first two stages of the model is to familiarize yourself with the availability of a new technological product, providing a brief overview and consumer interest.

- Advertising in TV films. This kind of communication has an impact on the younger generation. Seeing that the film's hero uses the device, consumers can step up their search for the information about the device.

- State educational programs. Unfortunately, in Ukraine, their role as a source of familiarity with the novelty is rather small, due to the lack of technological provision of educational institutions and students with the latest developments.

Stage 3 - Decision. A level of influence is conative, so circulation is realized in "pushing" the recipient to action (to purchase), prompting him of the expected actions from him. This stage actualizes other elements of communication influence - internet blogs, personal sales (personal consultation, product testing).

Stage 4 - Confirmation, Stage 5 - Implementation. A level of influence is suggestive and conative, that is, suggestion through both conscious psychological elements and elements of the unconscious and pushing to action. The result of suggestion can be conviction obtained without logical evidence and prompting the recipient of the expected actions from it. Strategies Internet blogs, Internet advertising, brand strategy, adventure strategy.

The communication channels on stage 3-5 will differ from the previous stages. The potential user has already received the main array of information from different sources and, in the future, will choose the most reliable sources, which will affect the final decision. In our opinion, it can be:

- Testing centres. It is very important before you decide to get familiar with the high-tech product, its software and functionality, to test it.

- The advice of friends and acquaintances.

- Customer's experience and his opinion. 
- The advice of vendors-consultants who can provide specific information that the consumer did not receive from other sources during the formation of the thought.

\section{Conclusions}

The research on the consumers' motivation in Ukrainian market of high-tech goods made it possible to find out that on the present stage of its development, the equal formation of the rational and emotional motivation is observed and certain emotional motives have the pronounced social orientation. The classification of consumer purchasing behaviour is influenced by two factors: the direction of the target consumer motivations development (rational, emotional, and socially-emotional) and consumer involvement in the purchase process. The purchasing behaviour types differ from one another by the character of purchasing decision, the degree of involvement in the purchasing process, the choice of information processing strategy, the number of market alternatives, which are evaluated, the time of purchasing decision.

Results show that highly rational, cautious, demonstrative behaviours can be observed in the case of high consumer involvement in the buying process. Rationally-confident, comfortable, adaptive behaviour can be observed in the case oflow involvement. Strategies of communicative influence and communication sources depend on consumer behavioural types and the stage of the process of adopting innovations. In the case of highly rational consumer behaviour, generic strategy, benefit strategy, unique technical advantage strategies are recommended to be used as the main communicative strategies. Benefit strategy, unique technical advantage strategy, positioning strategy should be used in the case of rationally confident behaviour. The technology of intrusion, intimidation, positioning strategy, affective strategy, and resonance strategy should be used in the case of cautious consumer behaviour. Brand strategy should be used in the case of demonstrative consumer behaviour. The communicative strategies of product positioning and the strategy of resonance can be used in the case of comfortable consumer behaviour. Brand strategy is the main communicative strategy in the case adaptive consumer behaviour. Communicative influence and communication sources depend on the stage of adopting innovations: 1) awareness, 2) attitude formation, 3) decision, 4) confirmation, 5) implementation. The main communicative channels on the first and second stage of the process of adopting innovations are: exhibition activity, TV advertising, outdoor and print advertising, Internet advertising, specialized publications, testing centres for goods, state educational programs. The main communication channels on the following stages are testing centres, the advice of friends and acquaintances, customer's experience, the advice of vendors-consultants.

Considering the structural shifts, which occur in the social-economic sphere from time to time and directly influence the consumer preferences and change their behavioural models, the research on transformations in consumer motivation must be conducted on a regular basis.

\section{References:}

Blackwell, R.D., Miniard, P.W., Engel J.F. (2006). Consumer Behaviour. Thomson/South-Western, 774.

De Pelsmacker, P., Geuens, M., Van den Bergh., J., (2010). Marketing Communications: A European Perspective. Financal Times Management, 660.

Duncan, T. (2002). IMC Using Advertising \& Promotion to Build Brands. New York: McGraw Hill, 783.

Hansen, T. (2005). Perspectives on consumer decision making: An integrated approach. Journal of Consumer Behaviour, 4(6): 420-437.

Mohr, J., Sengupta, S., Slater, S. (2010). Marketing of High-technology Products and Innovations. Upper Saddle River, NJ: Pearson/Prentice Hall.

Moore, G.A. (2014). Crossing the Chasm: Marketing and Selling High-Tech Products to Mainstream Customers or simply Crossing the Chasm. Harper Business Essentials, 227.

Percy, L. (1997). Strategy for Implementing Integrated Marketing Communication. Lincolnwood: NTC Books. Pirogova, Yu.K., Parshin, P.B. (2000). Advertising text: Semiotics and linguistics. Moscow: ID Grebennikova, 270. Solomon, M.R. (2012). Consumer Behaviour: Buying, Having, and Being. Upper Saddle River, NJ: Pearson Education, 640.

Vandecasteele, B., Geuens, M. (2011). Motivated Consumer Innovativeness: Concept, Measurement, and Validation. Advances in Consumer Research, Vol.38. [url]: http://www.acrwebsite.org/volumes/15867/volumes/ v38/NA-38.

Wells, V.K. (2014). The influence of behavioural psychology on consumer psychology and marketing. Journal of Marketing Management, 30 (11/12): 1119-1158. http://dx.doi.org/10.1080/0267257X.2014.929161 


\section{Виктория ЖУРИЛО, Ольга ПРИГАРА}

\section{ВЛИЯНИЕ МАРКЕТИНГОВЫХ КОММУНИКАЦИОННЫХ СТРАТЕГИЙ НА ПОВЕДЕНИЕ ПОТРЕБИТЕЛЕЙ НА РЫНКЕ ВЫСОКИХ ТЕХНОЛОГИЙ УКРАИНЫ}

Аннотация. Цель исследования - исследование типов поведения потребителей и разработка маркетинговых стратегий коммуникационного влияния на потребителя на рынке высокотехнологичных товаров Украины. Методология. Маркетинговые исследования на украинском рынке высокотехнологичных товаров проводились для определения мотиваций потребителей и особенностей их рыночного поведения. Были разработаны профили целевых клиентов и сформирована типология поведения потребителей, основанная на причинахпокупкивысокотехнологичныхтоваровинауровневовлеченностипотребителейвпроцессзакупок. Результаты показали, что в случае высокой потребительской вовлеченности в процесс покупки можно наблюдать такие типы потребительского поведения: очень рациональное, осторожное, демонстративное поведение. Рационально-уверенное, комфортное, адаптивное поведение может наблюдаться в случае низкой вовлеченности в процесс покупки. Определены особенности коммуникативного влияния для каждого типа потребительского поведения на рынке высокотехнологичных товаров и предложены соответствующие стратегии маркетинговой коммуникации. Практическая реализация. Стратегии коммуникативного влияния и коммуникационные каналы зависят от потребительских поведенческих типов и стадии процесса внедрения инноваций. В случае высоко рационального поведения потребителей, родовая стратегия, стратегии выгод, стратегии использования уникальных технологическихпреимуществ рекомендуется использовать в качестве основных коммуникативных стратегий. Стратегия преимуществ, уникальная стратегия технологических преимуществ, стратегия позиционирования должны использоваться в случае рационально уверенного поведения. В случае осторожного поведения потребителей следует использовать технологию вторжения, запугивания, стратегии позиционирования, аффективную стратегию и резонансную стратегию. Стратегия бренда должна использоваться в случае демонстративного поведения потребителей. Коммуникативные стратегии позиционирования продукта и стратегия резонанса могут быть использованы в случае комфортного поведения потребителей. Стратегия бренда является основной коммуникативной стратегией в случае адаптивного поведения потребителей. Коммуникативное влияние и источники коммуникации зависят от стадии принятия инноваций: 1) осведомленности, 2) формирования отношения, 3) решения, 4) подтверждения, 5) осуществления. Основными коммуникативными каналами на первом и втором этапах процесса внедрения инноваций являются: выставочная деятельность, телевизионная реклама, наружная и печатная реклама, интернет-реклама, специализированные издания, центры тестирования товаров, государственные образовательные программы. Основными коммуникационными каналами на следующих этапах являются центры тестирования, советы друзей и знакомых, опыт клиентов, советы поставщиковконсультантов. 